\title{
Alternative approaches to managing respiratory tract infections: a survey of public perceptions
}

\section{Alex Moore ${ }^{1}$, Rebecca Cannings-John ${ }^{2}$, Christopher C Butler ${ }^{3}$, Cliodna AM McNulty ${ }^{4}$, Nick A Francis ${ }^{5 *}$}

${ }^{1}$ School of Medicine, Cardiff University, Cardiff, UK; ${ }^{2}$ Centre for Trials Research, Cardiff University Neuadd Meirionnydd, Cardiff, UK; ${ }^{3}$ Nuffield Department of Primary Care Health Sciences, University of Oxford, Oxford, UK; ${ }^{4}$ Public Health England, Primary Care Unit, Gloucester, UK; ${ }^{5}$ School of Primary Care, Population Sciences, and Medical Education, University of Southampton, Southampton, UK

\begin{abstract}
Background: Respiratory tract infections (RTIs) are a common reason for people to consult in primary care, and contribute to antibiotic overuse and antimicrobial resistance (AMR). Alternative approaches to supporting patients with RTIs may help, but it is important to understand public perceptions about these approaches before they are widely implemented.
\end{abstract}

Aim: To describe public perceptions regarding finger-prick testing, back-up antibiotic prescriptions (BUPs), and alternatives to traditional consultations for RTIs, and identify factors associated with favouring these approaches.

Design \& setting: Online national survey (HealthWise Wales) with linked primary care health record data.

Method: Survey item response distributions were described. Associations between responses about consultation alternatives, BUP, and finger-prick point-of-care testing (POCT), and potential explanatory variables, were explored using logistic regression.

*For correspondence: nick. francis@soton.ac.uk

Competing interest: The authors declare that no competing interests exist.

Received: 14 July 2020 Accepted: 24 September 2020 Published: 03 March 2021

(C)This article is Open Access: CC BY license (https://creativecommons.org/licenses/by/4.0/)

Author Keywords: primary health care, respiratory tract infections, antimicrobial resistance, drug resistance, bacterial

Copyright (C) 2021, The Authors; DOI:10.3399/BJGPO.2020.0124
Results: A total of 8752 participants completed the survey between 2016 and 2018. The survey found $76.7 \%(n=3807 / 4,966)$ and $71.2 \%(n=3529 / 4,953)$ of responders with valid responses were in favour of being able to consult with a pharmacist or nurse in their GP surgery, or with a community pharmacist, respectively. It also showed $92.8 \%(n=8034 / 8659)$ of responders indicated they would be happy to have a finger-prick test to guide antibiotic prescribing, and $31.8 \%$ ( $n=2746 / 8646$ ) indicated they would like to be given a BUP if their clinician thought immediate antibiotics were not required. In addition, 47.4\% $(n=2342 / 4944)$ and $42.3 \%$ ( $n=2095 / 4949)$ were in favour of having video and email consultations, respectively. Characteristics associated with different response options were identified.

Conclusion: Consulting with pharmacists, using electronic communication tools, and finger-prick testing are widely acceptable approaches. BUP was described as acceptable less often, and is likely to require greater information and support when used.

\section{How this fits in}

Primary care services are struggling to keep up with the demand for RTI consultations, and the pressure to prescribe unnecessary antibiotics is driving antimicrobial resistance (AMR). This study explored public views about alternative approaches to traditional consultations through an online survey. There 
is scope for incorporating such interventions in current practice, to reduce the strain on GPs, although it is important to ensure adequate information and support are provided.

\section{Introduction}

RTIs are one of the most frequent reasons for consulting in primary care, with $27 \%$ of symptomatic people visiting a GP over a 12-month period. ${ }^{1}$ This contributes significantly to GP workload in the UK, which increased by $16 \%$ from $2007-2014 .^{2}$

AMR poses a threat to public health, worsens patient outcomes, and increases healthcare costs. ${ }^{3,4}$ Antibiotic consumption drives AMR at both individual and societal levels, ${ }^{5}$ and few new antibiotics are being developed. ${ }^{6}$ Primary care is responsible for $72 \%$ of healthcare-related antibiotic prescriptions ${ }^{7}$ and is, therefore, a key priority for tackling AMR. ${ }^{8}$ RTIs accounted for about half of all antibiotic prescriptions in UK primary care between 2013 and $2015 .{ }^{9}$ UK national guidance recommends that GPs do not prescribe antibiotics for most RTIs, ${ }^{10}$ but prescribing continues to be excessive. ${ }^{11,12}$

Alternatives to face-to-face GP consultations may help reduce the pressure on primary care services from RTIs, and use of antibiotics. Non-medical healthcare practitioners, such as pharmacists and nurses, are increasingly managing common infections. Some community pharmacists also provide services such as POCT to help determine the need for GP consultations or antibiotics. ${ }^{13}$ Telephone consultations have been used for years; video and email consultations are becoming more common, ${ }^{14}$ especially during the COVID-19 pandemic.

BUPs, also known as delayed antibiotic prescriptions, reduce antibiotic prescribing and consumption for RTIs, without increasing symptom burden, in clinical trials. ${ }^{15}$ BUPs aim to demedicalise minor infections and cut antibiotic use by empowering patients to share control over their treatment plan. ${ }^{16,17}$ POCT can help reduce antibiotic prescribing for RTIs in primary care. ${ }^{16,18}$ Rapid tests using biomarkers, such as C-reactive protein (CRP), can help reduce uncertainty about the need for antibiotics. ${ }^{19,20} \mathrm{GPs}$ report that use of POCT can reduce diagnostic uncertainty, but that costs and the effect on workflow are potential barriers. ${ }^{21}$

This study aimed to explore public perceptions regarding various approaches to consulting for RTIs, and perceptions about BUPs and POCT to target high levels of antibiotic use. Understanding public perceptions may help inform the implementation of different approaches to this challenging problem.

\section{Method}

A questionnaire was adminsitered as part of a national online cohort study in Wales, called HealthWise Wales (HWW). ${ }^{22}$ All adults (aged $\geq 16$ years) who are usually resident or receive their health care in Wales were eligible for inclusion in HWW. Participants were recruited through television, radio, and social media advertising campaigns, as well as promotion through the NHS (hospitals and GP surgeries), pharmacies, large employers, and at cultural events. HWW includes multiple cross-sectional surveys, encompassing general questionnaires and more focused areas of research. The sample consisted of HWW participants who completed a module (questionnaire) called, 'Caring for Coughs and Colds' (CCC). The module included 31 questions covering five domains: perceived consulting frequency; drivers of consulting; perceptions of serious illness; alternative sources of information; and views about alternative approaches to consulting for RTIs (Supplementary Table S1). Response options used 5-point Likert scales, ranging from 'strongly agree' to 'strongly disagree' and 'very much in favour' to 'completely against'. Questionnaire development was based on previously published studies; ${ }^{23}$ it used an iterative approach to develop items and a pilot questionnaire to refine items.

\section{Analysis}

Questionnaire responses were summarised using numbers and percentages for categorical variables, and mean and standard deviation for continuous data.

\section{Drivers of consulting}

After examining response distributions, the 5-point Likert scales for the drivers of consulting and components of a consultation domains were collapsed into binary outcomes of 'agree' ('strongly agree' or 'agree') and 'do not agree' ('neither agree nor disagree', or 'disagree', or 'strongly disagree') 
for ease of understanding and to allow for a logistic regression analysis. Multivariable logistic regression analyses were conducted to explore predictors of being in favour of: consulting with a community pharmacist; consulting with a pharmacist or nurse in a general practice; having a video consultation; having an email consultation; receiving a BUP; confidence in knowing when to take a BUP; and having a POCT.

\section{Perceived features of serious illness}

Response options for the domain on perceived features of serious illness were left as the original, wider 5-point scale ranging from 'very serious' to 'not serious at all'.

\section{Alternative sources of advice}

The first 3775 participants were mistakenly asked to respond to questions on sources of advice using either 'acceptable' or 'not acceptable'. Unfortunately, it is difficult to interpret these responses, and, therefore, they were not analysed leading to a high level of missing data for these questions. Questions on alternative sources of advice from the remaining responders were recorded using a 5-point Likert scale ranging from 'very much in favour' to 'completely against'. After examining the response distributions, these were collapsed into a three-point scale ('in favour', 'neither in favour nor against', and 'against') and then dichotomised into 'in favour' versus 'not in favour' ('neither in favour nor against' and 'against') and a logistic regression model was conducted to examine characteristics associated with favouring alternative sources of advice.

Data on personal characteristics were obtained from other core HWW modules. Levels of relative deprivation were calculated from home postcode using the Welsh Index of Multiple Deprivation (WIMD), a measure utilised by the Welsh Government. ${ }^{24}$ Consultation and antibiotic prescribing data were obtained through anonymous data linkage with primary care health record data held within the Secure Anonymised Information Linkage (SAIL) Databank. SAIL is an archive for personal, anonymised data, which can be linked on an individual level, ${ }^{25}$ and holds anonymised data for around $80 \%$ of Welsh GP surgeries. ${ }^{26}$ Read codes in the primary care record were used to identify consultations for the symptoms of an RTI and antibiotic prescriptions across a 3-year period from January 2015 to December 2017 (Supplementary Tables S2 and S3). SAIL data were also used to identify the
Table 1 Study participant characteristics ( $n=$ 8752)

\begin{tabular}{lc}
\hline Sex & $\begin{array}{l}\text { Frequency, } \\
\boldsymbol{n}(\%)\end{array}$ \\
\hline Male & $2273(26.1)$ \\
\hline Female & $6452(73.9)$ \\
\hline Missing & 27 \\
\hline
\end{tabular}

Age, years

\begin{tabular}{lc}
\hline$<30$ & $1522(17.4)$ \\
\hline $30-64$ & $5512(63.0)$ \\
\hline$\geq 65$ years & $1718(19.6)$ \\
\hline Missing & 0 \\
\hline Deprivation quintile & $975(11.5)$ \\
\hline 1 (most deprived) & $1427(16.8)$ \\
\hline 2 & $1710(20.1)$ \\
\hline 3 & $2279(26.8)$ \\
\hline 4 & $2108(24.8)$ \\
\hline 5 (least deprived) & 253 \\
\hline Missing & $5130(60.4)$ \\
\hline Rurality & $1507(17.7)$ \\
\hline Urban settlement $>10$ 000 & $1862(21.9)$ \\
\hline Town or fringe settlement & 253 \\
\hline Village, hamlet, and isolated dwellings
\end{tabular}

Current mental health problem

\begin{tabular}{lc} 
No & $6010(71.8)$ \\
\hline Yes & $2362(28.2)$ \\
\hline Missing & 380
\end{tabular}

History of mental illness

\begin{tabular}{lc} 
No & $5664(66.9)$ \\
\hline Yes & $2800(33.1)$ \\
\hline Missing & 288
\end{tabular}

\section{Marital status}

\begin{tabular}{lc}
\hline Not married & $1940(30.4)$ \\
\hline Married & $4445(69.6)$ \\
\hline Missing & 2367
\end{tabular}

\section{Have children}

\begin{tabular}{lc}
\hline No & $2998(35.8)$ \\
\hline Yes & $5375(64.2)$ \\
\hline Missing & 379
\end{tabular}

Smoking status

Never smoked $4756(56.2)$

continued on next page 
Table 1 Continued

\begin{tabular}{lc}
\hline Sex & $\begin{array}{l}\text { Frequency, } \\
\boldsymbol{n}(\%)\end{array}$ \\
\hline Previous smoker & $2890(34.2)$ \\
\hline Current smoker & $810(9.6)$ \\
\hline Missing & 296 \\
\hline
\end{tabular}

\section{Physical exercise in the past week}

\begin{tabular}{lc}
\hline None & $3107(36.7)$ \\
\hline Some but $<1$ hour & $1197(14.1)$ \\
\hline$\geq 1$ hour, but $<3$ hours & $1994(23.6)$ \\
\hline$\geq 3$ hours & $2166(25.6)$ \\
\hline Missing & 288 \\
\hline
\end{tabular}

\begin{tabular}{ll}
\hline Ever diagnosed with asthma & \\
\hline No & $5926(83.6)$ \\
\hline Yes & $1164(16.4)$ \\
\hline Missing & 1662
\end{tabular}

\begin{tabular}{lc}
\hline Ever diagnosed with DM & \\
\hline No & 6657 (93.9) \\
\hline Yes & $433(6.1)$ \\
\hline Missing & 1662
\end{tabular}

\section{Ever diagnosed with CVD}

\begin{tabular}{lc}
\hline No & $6854(96.7)$ \\
\hline Yes & $236(3.3)$ \\
\hline Missing $^{\text {a }}$ & 1662
\end{tabular}

Ever diagnosed with COPD

\begin{tabular}{lc}
\hline No & $7032(99.2)$ \\
\hline Yes & $58(0.8)$ \\
\hline Missing $^{\text {a }}$ & 1662 \\
\hline Consulting frequency & \\
\hline Never & $4866(71.4)$ \\
\hline Less than once a year & $1076(15.8)$ \\
\hline About once a year & $812(11.9)$ \\
\hline Twice or more per year & $65(1.0)$ \\
\hline Missing $^{\text {a }}$ & 1933
\end{tabular}

Antibiotic prescribing frequency

\begin{tabular}{lc}
\hline Less than once a year & $5791(81.7)$ \\
\hline Once or more per year & $1299(18.3)$ \\
\hline Missing & 1662 \\
\hline
\end{tabular}

${ }^{a}$ Owing to non-linkage. COPD = chronic obstructive pulmonary disease. CVD = cardiovascular disease. DM

$=$ diabetes mellitus.

(for 3 weeks), noisy and wheezy cough, and green phlegm (Figure 2). presence of Read codes for four key comorbidities (asthma, diabetes mellitus [DM], cardiovascular disease [CVD], and chronic obstructive pulmonary disease [COPD]) (Supplementary Table S4).

For the regression models, the following pre-hypothesised explanatory variables were used: sex; age; deprivation quintile; rurality; current mental health problem; history of mental health problem; marital status; having children; smoking status; reported physical exercise; the four comorbid conditions (asthma, DM, CVD, COPD); consulting and prescribing frequency; and responses to three of the questionnaire items on symptoms reflecting infection seriousness (perception of a cough lasting 1 week or more, perception of a cough with green phlegm lasting 2 days or more, perception of a noisy and wheezy chest). For each analysis, the univariable association between outcome and each independent variable was calculated, and variables associated with outcome at $P=0.1$ were entered into a multivariable analysis. Results from the models are reported as odds ratios (ORs) with $95 \%$ confidence intervals (Cls).

\section{Results}

A total of 8752 participants completed the HWW CCC module between October 2016 and April 2018. Study participant characteristics are presented in Table 1. Just under three-quarters were female, and the mean (standard deviation) age was $49^{17}$ years. In total, 4387 (51.6\%) came from the two most affluent quintiles, and only $12 \%$ coming from the most deprived. Less than $10 \%$ were current smokers, and just over a third reported that they had not engaged in any exercise in the past week. Responses to questions about alternative sources of health information from the first 3775 (43.1\%) participants were discarded because of an error in the response options for these participants. There were no marked differences observed between responders retained in the main analysis and those excluded owing to response options (Supplementary Table S5). A total of 1662 (19\%) participants could not be linked to GP data within SAIL.

The most common reason for deciding to consult about an RTI was worry about an infection being serious ( $90.5 \%$ of participants). However, perceived need for an antibiotic prescription was also an important driver (Figure 1). The illness features most associated with a perception of serious illness were fever, prolonged dry cough phlegm (Figure 2). 


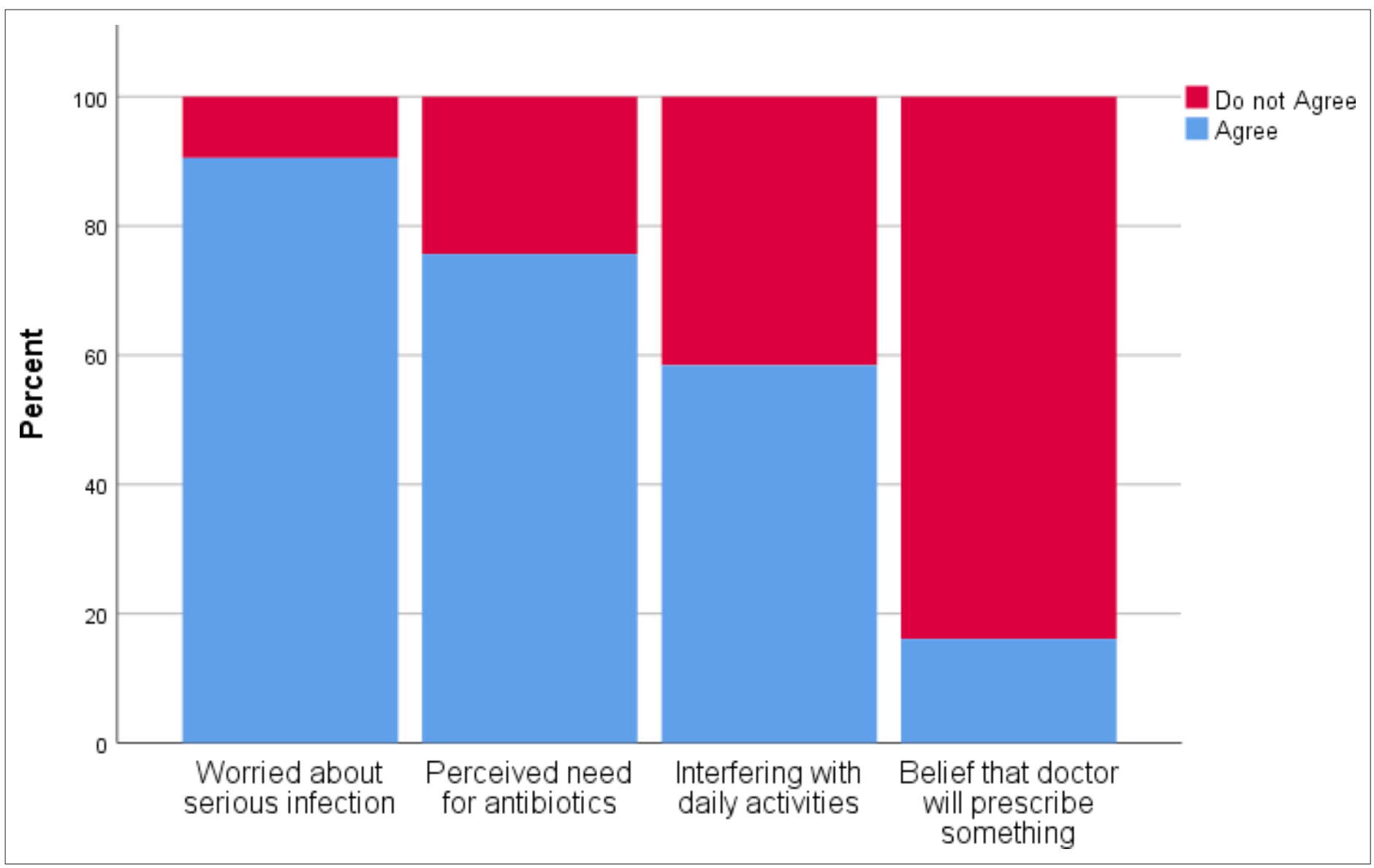

Figure 1 Public perceptions of reasons to consult a healthcare professional for a respiratory tract infection

Of the 4966 participants who completed a question about consulting for an RTI with a pharmacist or nurse in their usual GP surgery, 76.7\% $(n=3807)$ were in favour (Figure 3). Of the 4953 participants who completed the question about consulting with a community pharmacist with training in assessing RTIs, 71.2\% ( $n=3529 / 4953$ ) were in favour (Figure 3). While $47.4 \%(n=2342 / 4944)$ and $42.3 \%$ ( $n=$ 2095/4949) were in favour of having video and email consultations for RTIs, respectively. It was found that $31.8 \%(n=2746 / 8646)$ and $92.8(n=8034 / 8659)$ were in favour of having a BUP and fingerprick blood tests, respectively. These proportions did not vary significantly by socioeconomic status (Table 2).

Female sex was associated with being in favour of consulting with a local pharmacist or pharmacist or nurse in their own surgery (Table 3). Adults without children were more likely to favour being seen by a local pharmacist than parents, and individuals who thought that a 1-week cough was serious, a marker of increased concern about RTI symptoms, were more likely to accept a pharmacist or nurse consultation (Table 3). Younger (aged <65 years) and sedentary (no weekly exercise) participants, and those not reporting a mental health problem, were more in favour of video consultations (Table 3). Similarly, younger participants, and those who believed having a wheezy chest is an indicator of serious infection were more likely to favour email consultations.

\section{Back-up prescriptions and finger-prick blood tests}

A total of 2746 (31.8\%) agreed they would like to be given a BUP if their clinician thought they did not need immediate antibiotics. While 2922 (33.8\%) responders indicated that they would not feel comfortable in knowing when to take a BUP. There was an association between socioeconomic deprivation and wanting to be given a BUP, with those from more deprived backgrounds being more in favour of this approach (Table 2). However, in a multivariable analysis socioeconomic status was not significant. Those who reported that they would be happy to receive a BUP being more likely to be male, young, have a current mental health problem, be a parent and be sedentary (report not engaging 


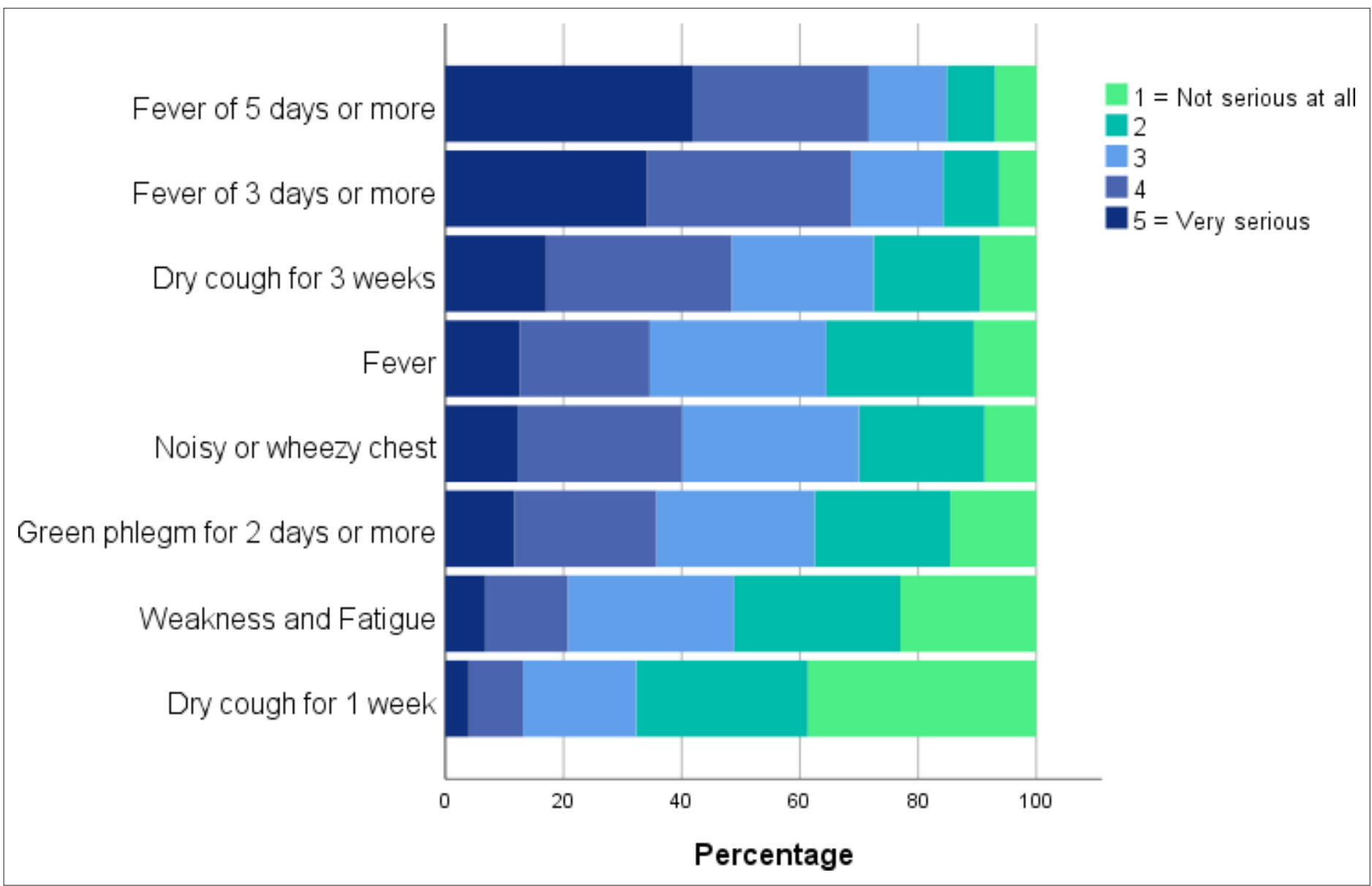

Figure 2 Public perceptions of seriousness of features associated with respiratory tract infections.

in any exercise). A history of COPD was associated with twice the odds of wanting to be given a BUP. Consulting less frequently, receiving antibiotics more frequently, and having greater concern about symptoms (believing that a 1-week cough and a noisy, wheezy chest are indicators of serious infection) were all associated with a greater odds of wanting to be offered a BUP. Women, younger adults (aged $<30$ years), those who are more sedentary and those who consulted less frequently, were all more likely to indicate that they would not feel comfortable in knowing when to take a BUP if they were given one (Table 3).

A total of 8034 (92.8\%) participants agreed that they would generally be happy to be offered a finger-prick blood test to help guide antibiotic treatment during a consultation. Women, younger people, smokers (current and previous) and frequent antibiotic recipients were less likely to report finger-prick blood testing acceptable (Table 3).

\section{Discussion}

\section{Summary}

Key findings in this survey of public perceptions about consulting for RTls are that more than $90 \%$ of responders indicated that they would be happy to have a finger-prick blood test in primary care to help inform the need for antibiotics, and around three-quarters would be happy to consult with a community pharmacist, nurse, or pharmacist in their surgery. Women, adults without children, and people with greater concern about the seriousness of cough, were more in favour of having the option of consulting with non-medical practitioners. Less than half of responders thought electronic consultations (video or email) were acceptable, with younger people being more in favour of this 


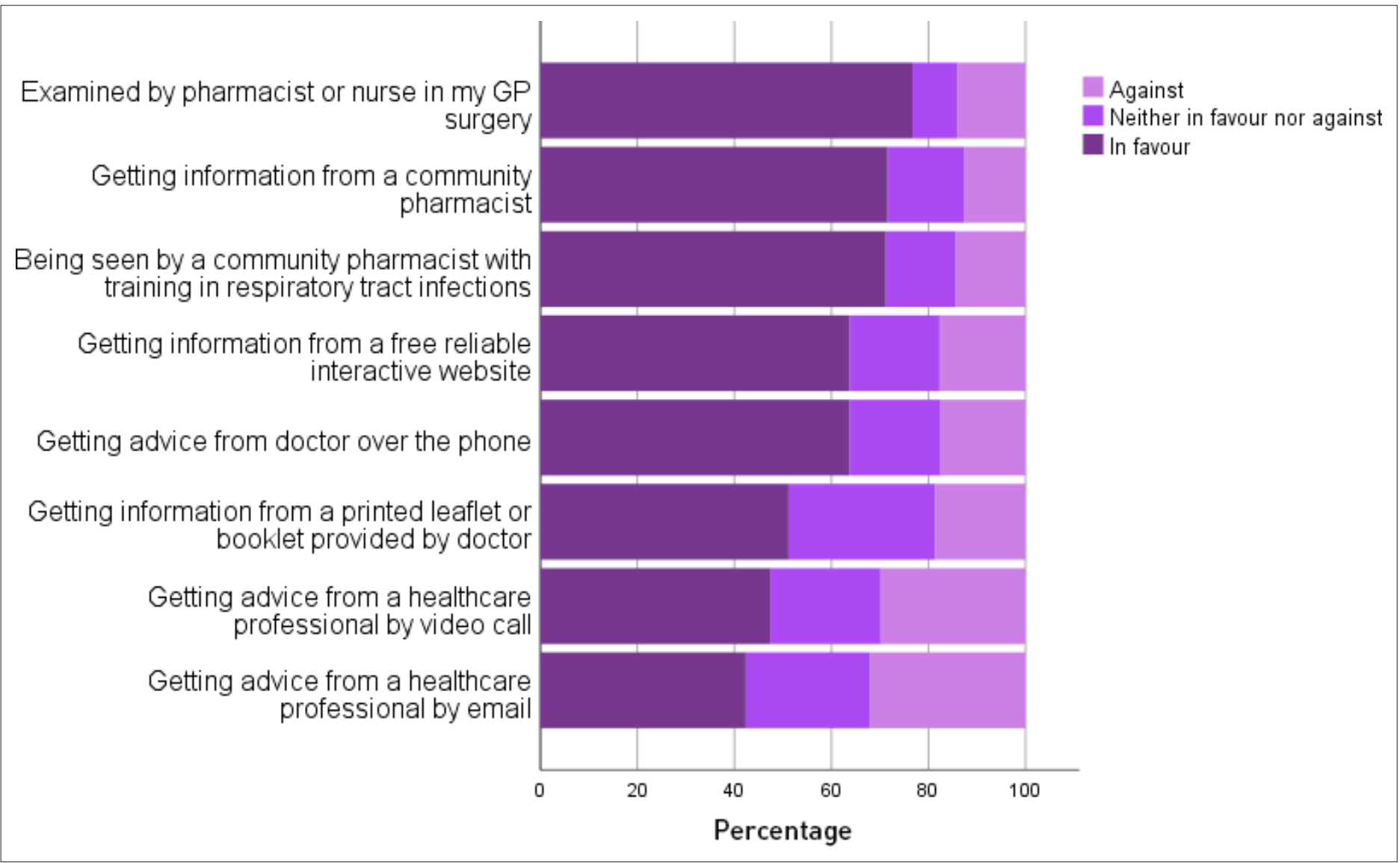

Figure 3 Public views about possible sources of advice or information for respiratory tract infections

approach. Less than a third of participants indicated they would want to be given a BUP, and a third said they would not feel comfortable deciding when to use a BUP.

\section{Strengths and limitations}

The study benefited from being able to link perceptions reported in an online survey to primary care health record data. Data were obtained from over 8700 people; however, the study had over-

Table 2 Variation in responses by socioeconomic status

\begin{tabular}{|c|c|c|c|c|c|c|c|}
\hline \multicolumn{8}{|c|}{ Deprivation quintile } \\
\hline Variable & $\begin{array}{l}1 \text { most } \\
\text { deprived }\end{array}$ & 2 & 3 & 4 & $\begin{array}{l}5 \text { least } \\
\text { deprived }\end{array}$ & Missing & Total \\
\hline \multicolumn{8}{|l|}{ In favour of: } \\
\hline $\begin{array}{l}\text { Consulting with pharmacist or } \\
\text { nurse in practice }\end{array}$ & $\begin{array}{c}376 / 498 \\
(75.5)\end{array}$ & $\begin{array}{l}588 / 783 \\
(75.1)\end{array}$ & $\begin{array}{l}714 / 920 \\
(77.6)\end{array}$ & $\begin{array}{l}1088 / 1425 \\
(76.4)\end{array}$ & $\begin{array}{l}918 / 1187 \\
(77.6)\end{array}$ & $\begin{array}{c}123 / 153 \\
(80.4)\end{array}$ & $\begin{array}{l}3807 / 4966 \\
(76.7)\end{array}$ \\
\hline $\begin{array}{l}\text { Consulting with community } \\
\text { pharmacist }\end{array}$ & $\begin{array}{c}347 / 494 \\
(70.2)\end{array}$ & $\begin{array}{l}556 / 783 \\
(71.0)\end{array}$ & $\begin{array}{l}650 / 918 \\
(70.8)\end{array}$ & $\begin{array}{c}1006 / 1422 \\
(70.7)\end{array}$ & $\begin{array}{l}859 / 1182 \\
(72.7)\end{array}$ & $\begin{array}{l}111 / 154 \\
(72.1)\end{array}$ & $\begin{array}{l}3529 / 4953 \\
\quad(71.2)\end{array}$ \\
\hline Video consultation & $\begin{array}{l}245 / 494 \\
(49.6)\end{array}$ & $\begin{array}{c}357 / 779 \\
(45.8)\end{array}$ & $\begin{array}{c}434 / 916 \\
(47.4)\end{array}$ & $\begin{array}{l}632 / 1420 \\
(44.5)\end{array}$ & $\begin{array}{l}607 / 1184 \\
(51.3)\end{array}$ & $\begin{array}{c}67 / 151 \\
(44.4)\end{array}$ & $\begin{array}{l}2342 / 4944 \\
(47.4)\end{array}$ \\
\hline Email consultation & $\begin{array}{c}220 / 492 \\
(44.7)\end{array}$ & $\begin{array}{c}325 / 780 \\
(41.7)\end{array}$ & $\begin{array}{l}377 / 915 \\
(41.2)\end{array}$ & $\begin{array}{c}613 / 1421 \\
(43.1)\end{array}$ & $\begin{array}{l}493 / 1187 \\
(41.5)\end{array}$ & $\begin{array}{c}67 / 154 \\
(43.5)\end{array}$ & $\begin{array}{l}2095 / 4949 \\
(42.3)\end{array}$ \\
\hline Back-up prescription & $\begin{array}{l}351 / 963 \\
(36.4)\end{array}$ & $\begin{array}{c}469 / 1411 \\
(33.2)\end{array}$ & $\begin{array}{l}542 / 1685 \\
(32.2)\end{array}$ & $\begin{array}{c}678 / 2251 \\
(30.1)\end{array}$ & $\begin{array}{l}624 / 2085 \\
(29.9)\end{array}$ & $\begin{array}{c}82 / 251 \\
(32.7)\end{array}$ & $\begin{array}{c}2746 / 8646 \\
(31.8)\end{array}$ \\
\hline Finger-prick blood test & $\begin{array}{c}875 / 958 \\
(91.3)\end{array}$ & $\begin{array}{c}1276 / 1416 \\
(90.1)\end{array}$ & $\begin{array}{c}1572 / 1690 \\
(93.0)\end{array}$ & $\begin{array}{c}2110 / 2257 \\
\quad(93.5)\end{array}$ & $\begin{array}{c}1966 / 2087 \\
(94.2)\end{array}$ & $\begin{array}{c}235 / 251 \\
(93.6)\end{array}$ & $\begin{array}{c}8034 / 8659 \\
(92.8)\end{array}$ \\
\hline
\end{tabular}

All results reported as $n / N(\%)$ 
Table 3 Summarised results for the multivariable analysis to identify associations between explanatory and outcome variables

\begin{tabular}{|c|c|c|c|c|c|c|c|}
\hline & $\begin{array}{c}\text { Local } \\
\text { pharmacist }^{a}\end{array}$ & $\begin{array}{c}\text { Pharmacist or } \\
\text { nurse }^{a}\end{array}$ & $\begin{array}{c}\text { Video } \\
\text { consultation }^{\mathrm{a}}\end{array}$ & Emaila $^{a}$ & Receive BUP ${ }^{b}$ & Take BUP & POCT $^{\mathrm{b}}$ \\
\hline & \multicolumn{7}{|c|}{ Adjusted $\mathrm{OR}^{\mathrm{c}}(95 \% \mathrm{Cl})$} \\
\hline \multicolumn{8}{|l|}{ Sex } \\
\hline Male (reference) & 1.00 & 1.00 & & & 1.00 & 1.00 & 1.00 \\
\hline Female & $\begin{array}{c}1.48 \\
(1.29 \text { to } 1.71)\end{array}$ & $\begin{array}{c}1.46 \\
(1.26 \text { to } 1.70)\end{array}$ & & & $\begin{array}{c}0.80 \\
(0.70 \text { to } 0.91)\end{array}$ & $\begin{array}{c}1.18 \\
(1.02 \text { to } 1.37)\end{array}$ & $\begin{array}{c}0.64 \\
(0.49 \text { to } 0.83)\end{array}$ \\
\hline \multicolumn{8}{|l|}{ Age, years } \\
\hline$<30$ (reference) & 1.00 & & 1.00 & 1.00 & 1.00 & 1.00 & 1.00 \\
\hline $30-64$ & $\begin{array}{c}1.19 \\
(0.97 \text { to } 1.46)\end{array}$ & & $\begin{array}{c}1.03 \\
(0.85 \text { to } 1.24)\end{array}$ & $\begin{array}{c}0.73 \\
(0.55 \text { to } 0.97)\end{array}$ & $\begin{array}{c}0.79 \\
(0.66 \text { to } 0.94)\end{array}$ & $\begin{array}{c}0.49 \\
(0.40 \text { to } 0.61)\end{array}$ & $\begin{array}{c}1.43 \\
(1.12 \text { to } 1.82)\end{array}$ \\
\hline$\geq 65$ & $\begin{array}{c}1.01 \\
(0.80 \text { to } 1.29)\end{array}$ & & $\begin{array}{c}0.75 \\
(0.59 \text { to } 0.96)\end{array}$ & $\begin{array}{c}0.62 \\
(0.44 \text { to } 0.88)\end{array}$ & $\begin{array}{c}0.96 \\
(0.77 \text { to } 1.20)\end{array}$ & $\begin{array}{c}0.51 \\
(0.39 \text { to } 0.68)\end{array}$ & $\begin{array}{c}1.65 \\
\text { (1.16 to } 2.35)\end{array}$ \\
\hline \multicolumn{8}{|l|}{ Deprivation quintile } \\
\hline 1 (most deprived) (reference) & & & 1.00 & & 1.00 & & 1.00 \\
\hline 2 & & & $\begin{array}{c}0.84 \\
(0.65 \text { to } 1.08)\end{array}$ & & $\begin{array}{c}0.86(0.70 \text { to } \\
1.05)\end{array}$ & & $\begin{array}{c}0.80(0.58 \text { to } \\
1.10)\end{array}$ \\
\hline 3 & & & $\begin{array}{c}0.88 \\
(0.68 \text { to } 1.13)\end{array}$ & & $\begin{array}{c}0.83(0.68 \text { to } \\
1.01)\end{array}$ & & $\begin{array}{c}1.28(0.91 \text { to } \\
1.80)\end{array}$ \\
\hline 4 & & & $\begin{array}{c}0.82 \\
(0.64 \text { to } 1.05)\end{array}$ & & $\begin{array}{c}0.87(0.72 \text { to } \\
1.05)\end{array}$ & & $\begin{array}{c}1.11(0.80 \text { to } \\
1.54)\end{array}$ \\
\hline 5 (least deprived) & & & $\begin{array}{c}0.99 \\
(0.78 \text { to } 1.26)\end{array}$ & & $\begin{array}{c}0.86(0.71 \text { to } \\
1.04)\end{array}$ & & $\begin{array}{c}1.36(0.97 \text { to } \\
1.90)\end{array}$ \\
\hline \multicolumn{8}{|l|}{ Rurality } \\
\hline Urban settlement >10 000 (reference) & & & 1.00 & 1.00 & & 1.00 & \\
\hline Town or fringe settlement & & & $\begin{array}{c}0.92 \\
(0.76 \text { to } 1.12)\end{array}$ & $\begin{array}{c}0.96(0.76 \text { to } \\
1.21)\end{array}$ & & $\begin{array}{c}1.02(0.85 \text { to } \\
1.21)\end{array}$ & \\
\hline Village, hamlet, and isolated dwellings & & & $\begin{array}{c}1.03 \\
(0.85 \text { to } 1.24)\end{array}$ & $\begin{array}{c}0.90(0.73 \text { to } \\
1.10)\end{array}$ & & $\begin{array}{c}0.98(0.83 \text { to } \\
1.16)\end{array}$ & \\
\hline \multicolumn{8}{|l|}{ Current mental health problem } \\
\hline No (reference) & & & 1.00 & & 1.00 & 1.00 & 1.00 \\
\hline Yes & & & $\begin{array}{c}0.83 \\
(0.71 \text { to } 0.97)\end{array}$ & & $\begin{array}{c}1.24(1.09 \text { to } \\
1.41)\end{array}$ & $\begin{array}{c}1.03(0.88 \text { to } \\
1.19)\end{array}$ & $\begin{array}{c}0.94(0.76 \text { to } \\
1.17)\end{array}$ \\
\hline
\end{tabular}

\section{History of mental illness}

\begin{tabular}{lc} 
No (reference) & 1.00 \\
\hline Yes & 1.12 \\
& $(0.97$ to 1.30$)$
\end{tabular}

\section{Marital status}

Not married (reference)

Married

1.00
$0.93(0.76$ to
$1.15)$

1.00

1.15)

$1.00(0.85$ to

\section{Have children}

No (reference)

Yes

1.00
0.82
$(0.70$ to 0.95$)$

\section{Smoking status}

Never smoked (reference)

Previous smoker

\begin{tabular}{|c|c|c|}
\hline 1.00 & 1.00 & 1.00 \\
\hline $\begin{array}{c}1.04 \text { (0.85 to } \\
1.29)\end{array}$ & $\begin{array}{c}1.17(1.02 \text { to } \\
1.34)\end{array}$ & $\begin{array}{c}1.00(0.85 \text { to } \\
1.18)\end{array}$ \\
\hline
\end{tabular}

(0.94 to 1.27)

1.00
1.09
$(0.94$ to 1.27$)$

\begin{tabular}{ccc}
1.00 & 1.00 & 1.00 \\
$\begin{array}{c}1.08(0.95 \text { to } \\
1.22)\end{array}$ & $0.92(0.80$ to & $0.99(0.79$ to \\
& $1.06)$ & $1.23)$ \\
\hline & Continued on next page
\end{tabular}


Table 3 Continued

\begin{tabular}{|c|c|c|c|c|c|c|c|}
\hline & $\begin{array}{c}\text { Local } \\
\text { pharmacist }^{\mathrm{a}}\end{array}$ & $\begin{array}{c}\text { Pharmacist or } \\
\text { nurse }^{\mathrm{a}}\end{array}$ & $\begin{array}{c}\text { Video } \\
\text { consultation }^{\mathrm{a}}\end{array}$ & Email $^{a}$ & Receive BUP & Take BUP & $\mathbf{P O C T}^{\mathrm{b}}$ \\
\hline Current smoker & & & $\begin{array}{c}0.83 \\
(0.65 \text { to } 1.06)\end{array}$ & & $\begin{array}{c}1.17 \text { (0.96 to } \\
1.42)\end{array}$ & $\begin{array}{c}0.99(0.78 \text { to } \\
1.25)\end{array}$ & $\begin{array}{c}0.72(0.54 \text { to } \\
0.98)\end{array}$ \\
\hline \multicolumn{8}{|c|}{ Physical exercise in the past week } \\
\hline None (reference) & & & 1.00 & 1.00 & 1.00 & 1.00 & 1.00 \\
\hline Some but $<1$ hour & & & $\begin{array}{c}1.26 \\
\text { (1.02 to } 1.56)\end{array}$ & $\begin{array}{c}0.79(0.61 \text { to } \\
1.02)\end{array}$ & $\begin{array}{c}0.87(0.73 \text { to } \\
1.03)\end{array}$ & $\begin{array}{c}1.18(0.97 \text { to } \\
1.43)\end{array}$ & $\begin{array}{c}1.01(0.76 \text { to } \\
1.36)\end{array}$ \\
\hline$\geq 1$ hour but $<3$ hours & & & $\begin{array}{c}1.20 \\
(1.00 \text { to } 1.43)\end{array}$ & $\begin{array}{c}1.13(0.92 \text { to } \\
1.39)\end{array}$ & $\begin{array}{c}0.83(0.72 \text { to } \\
0.97)\end{array}$ & $\begin{array}{c}0.93(0.79 \text { to } \\
1.10)\end{array}$ & $\begin{array}{c}1.01(0.78 \text { to } \\
1.30)\end{array}$ \\
\hline$\geq 3$ hours & & & $\begin{array}{c}1.21 \\
\text { (1.01 to } 1.44)\end{array}$ & $\begin{array}{c}1.15(0.94 \text { to } \\
1.41)\end{array}$ & $\begin{array}{c}0.81(0.70 \text { to } \\
0.94)\end{array}$ & $\begin{array}{c}0.79(0.66 \text { to } \\
0.93)\end{array}$ & $\begin{array}{c}1.13(0.86 \text { to } \\
1.47)\end{array}$ \\
\hline
\end{tabular}

\section{Ever diagnosed with asthma}

No (reference)

Yes

\section{Ever diagnosed with DM}

No (reference)

Yes

1.00

$1.20(0.95$ to

1.50)

\section{Ever diagnosed with CVD}

No (reference)

Yes

\begin{tabular}{ccc}
1.00 & 1.00 & 1.00 \\
\hline 0.84 & 0.67 & 1.19 \\
$(0.56$ to 1.26$)$ & $(0.41$ to 1.09$)$ & $(0.87$ to 1.62$)$
\end{tabular}

Ever diagnosed with COPD

No (reference)

Yes

1.00

2.27

(1.21 to 4.27$)$

\section{Consulting frequency}

Never (reference)

Less than once a year

About once a year

Twice or more per year

\begin{tabular}{cccc}
1.00 & 1.00 & 1.00 & 1.00 \\
\hline 1.01 & 1.25 & 0.93 & 1.36 \\
0.81 to 1.26$)$ & $(1.07$ to 1.46$)$ & $(0.78$ to 1.11$)$ & $(1.02$ to 1.82$)$ \\
0.86 & 1.27 & 0.71 & 1.20 \\
0.66 to 1.12$)$ & $(1.05$ to 1.54$)$ & $(0.57$ to 0.88$)$ & $(0.87$ to 1.66$)$ \\
0.88 & 1.32 & 1.36 & 1.34 \\
0.37 to 2.08$)$ & $(0.75$ to 2.33$)$ & $(0.71$ to 2.63$)$ & $(0.56$ to 3.17$)$
\end{tabular}

Antibiotic prescribing frequency

Less than once a year (reference)

Once or more per year

1.00

0.87

(0.69 to 1.10$)$

$\frac{1.00}{1.51}$

(1.23 to 1.85$)$
1.00

0.58

(0.42 to 0.80$)$

\section{Perception of 1-week cough}

Not serious (reference)

1.00
1.33
1.08 to 1.65$)$

Serious

(1.08 to 1.65$)$

\section{Perception of green phlegm for 2}

days

Not serious (reference)

Serious

1.00
1.08
0.95 to 1.23

$\begin{array}{cc}1.00 & 1.00 \\ 1.61 & 0.85 \\ .37 \text { to } 1.89) & (0.70 \text { to } 1.02)\end{array}$


Table 3 Continued

\begin{tabular}{|c|c|c|c|c|c|c|c|}
\hline & $\begin{array}{c}\text { Local } \\
\text { pharmacist }^{\mathrm{a}}\end{array}$ & $\begin{array}{c}\text { Pharmacist or } \\
\text { nurse }^{\mathrm{a}}\end{array}$ & $\begin{array}{c}\text { Video } \\
\text { consultation }^{\mathrm{a}}\end{array}$ & Email $^{\mathrm{a}}$ & Receive BUP ${ }^{b}$ & Take BUP ${ }^{b}$ & POCT $^{\mathrm{b}}$ \\
\hline \multicolumn{8}{|c|}{$\begin{array}{l}\text { Perception of noisy and wheezy } \\
\text { chest }\end{array}$} \\
\hline Not serious (reference) & & & & 1.00 & 1.00 & & 1.00 \\
\hline Serious & & & & $\begin{array}{c}0.85 \\
(0.72 \text { to } 1.00)\end{array}$ & $\begin{array}{c}1.24 \\
(1.09 \text { to } 1.41)\end{array}$ & & $\begin{array}{c}0.86 \\
(0.691 .07)\end{array}$ \\
\hline
\end{tabular}

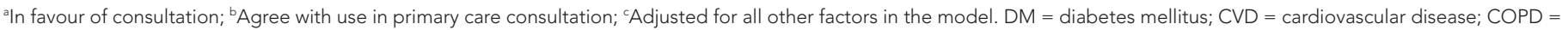
chronic obstructive pulmonary disease.

representation of females (73.9\% female compared with $50.7 \%$ of the UK population), ${ }^{27}$ and middleaged (30-64-year-old age group) participants. The survey was only available to those with internet access between October 2016 and April 2018, which was 85\% of Welsh households in $2018 .{ }^{28}$ The responders were on average less socioeconomically deprived than the general population, which is likely why the study had a lower proportion of current smokers than in the general population. Nevertheless, the authors were able to include large numbers from all socioeconomic groups and control for socioeconomic status in the analyses. An association was found between socioeconomic status and views about use of BUP, but this was not significant in a multivariable analysis, and no other significant associations were found with socioeconomic status. A total of 3775 (43\%) of the sample was lost owing to a mistake with response outcomes; however, the excluded samples and those retained were broadly similar and appears to exhibit little bias. Finally, views expressed in an online survey may differ from those expressed in other settings or following greater provision of information. For example, questions about BUP may have differed if responders had a more detailed understanding of the reasons for using this approach and how it works.

\section{Comparison with existing literature}

How people appraise their symptoms and perceive the severity of their illness was identified as a key driver of consulting in a previous qualitative study and survey of adults across England. ${ }^{23}$ Women were more likely to consult, but there were no differences by age or region in this study. Worry about cough has previously been shown as a driver of consulting in general practice. ${ }^{29}$ It was found that those who perceived a 1-week cough as serious were more likely to indicate that consulting with a pharmacist would be acceptable. This suggests that those with greater concern about RTI symptoms want different consultation options, but this needs confirming.

A 2014 public survey found a similar proportion (just over a third favouring or strongly favouring) BUP or delayed prescriptions, as in the present study (31.8\%). ${ }^{30}$ Their findings are consistent with the present study's finding that women and older people are less likely to favour delayed or BUP antibiotics, but they also found that women and parents were more aware of BUPs. ${ }^{31}$ Perceptions about deciding when to use BUP antibiotics were also explored and it was found that a third were not comfortable making this decision. A previous qualitative interview study found that most patients were happy to be given BUP, but some found it confusing to be issued a prescription after being told that it was viral. ${ }^{32} \mathrm{~A}$ similar study in Australia identified concerns about the use of BUP, and, in particular, knowing when to take them. ${ }^{33}$ GPs have expressed mixed views about BUPs. ${ }^{34,35}$

\section{Implications for research and practice}

The findings support the view that several approaches to managing RTIs are likely to be acceptable to the public. Pharmacists, nurses, and allied health professionals already play an important role in managing RTls, and the findings suggest that many value these options, with men and parents reporting less acceptance. These findings may help those designing services, and further research could explore the reasons for these differences. Less enthusiasm was found for digital (video and email) consultations for RTIs. Previous qualitative research has found that this approach is generally very acceptable to patients, although technical issues can be a barrier to use. ${ }^{36,37}$ In the context of the COVID-19 pandemic, remote consultations have become the norm, and it would be interesting to see how public perceptions on use of these technologies have changed. 
It is encouraging to see that more than $90 \%$ were happy to have a finger-prick blood test to help guide antibiotic prescribing. POCT can improve antibiotic prescribing for $\mathrm{RTIs}^{16}{ }^{16}$ including acute exacerbations of COPD. ${ }^{38}$ The findings suggest that members of the public have mixed views about the role of BUPs. There is clearly a need for more public information about BUPs, including a rationale for use of BUP and clear instructions on when to initiate them. These findings can be used to help develop strategies to improve the management of RTI and reduce the use of antibiotics in primary care.

\section{Funding}

This study received no direct external funding, but was supported by Healthwise Wales, which is funded by the Welsh Assembly Government through Health and Care Research Wales.

\section{Ethical approval}

Healthwise Wales received ethical approval from Wales Research Ethics Committee (REC) 3 on 16 March 2015 (reference 15/WA/0076). A substantial amendment was submitted when the Caring for Coughs and Colds module was added and this received approval from Wales REC 3 on 13/10/2016.

\section{Provenance}

Freely submitted; externally peer reviewed.

\section{Acknowledgements}

This study was facilitated by HealthWise Wales, the Health and Care Research Wales initiative, which is led by Cardiff University in collaboration with SAIL, Swansea University. We would like to acknowledge the Healthwise Wales team who supported the study (Pauline Ashfield-Watt, Ameeta Richardson, and others), Fiona Lugg-Widger, who helped develop the questionnaire, and the Healthwise Wales study participants.

\section{References}

1. McNulty CAM, Collin SM, Cooper E, et al. Public understanding and use of antibiotics in England: findings from a household survey in 2017. BMJ Open 2019; 9(10): e030845. DOI: https://doi.org/10.1136/bmjopen-2019-030845

2. Hobbs FDR, Bankhead C, Mukhtar T, et al. Clinical workload in UK primary care: a retrospective analysis of 100 million consultations in England, 2007-14. Lancet 2016; 387(10035): 2323-2330. DOI: https://doi.org/10.1016/ S0140-6736(16)00620-6

3. Aryee A, Price N. Antimicrobial stewardship — can we afford to do without it? Br J Clin Pharmacol 2015; 79(2): 173-181. DOI: https://doi.org/10.1111/bcp.12417

4. Cosgrove SE, Carmeli Y. The impact of antimicrobial resistance on health and economic outcomes. Clin Infect Dis 2003; 36(11): 1433-1437. DOI: https://doi.org/10.1086/375081

5. Bell BG, Schellevis F, Stobberingh E, et al. A systematic review and meta-analysis of the effects of antibiotic consumption on antibiotic resistance. BMC Infect Dis 2014; 14: 13. DOI: https://doi.org/10.1186/1471-2334-14-13

6. Cars O, Högberg LD, Murray M, et al. Meeting the challenge of antibiotic resistance. BMJ 2008; 337: a1438. DOI: https://doi.org/10.1136/bmj.a1438

7. Public Health England. English surveillance programme for antimicrobial utilisation and resistance (ESPAUR). Report 2018-2019. London: Public Health England; 2018. https://webarchive.nationalarchives.gov.uk/20200806045257/ https://www.gov.uk/government/publications/english-surveillance-programme-antimicrobial-utilisation-andresistance-espaur-report

8. Costelloe $\mathrm{C}$, Metcalfe $\mathrm{C}$, Lovering A, et al. Effect of antibiotic prescribing in primary care on antimicrobial resistance in individual patients: systematic review and meta-analysis. BMJ 2010; 340(7756): c2096. DOI: https://doi.org/10. 1136/bmj.c2096

9. Dolk FCK, Pouwels KB, Smith DRM, et al. Antibiotics in primary care in England: which antibiotics are prescribed and for which conditions? J Antimicrob Chemother 2018; 73(suppl_2): ii2-ii10. DOI: https://doi.org/10.1093/jac/ $\mathrm{dkx504}$

10. National Institute for Health and Care Excellence, Public Health England. Summary of antimicrobial prescribing guidance - managing common infections. 2020; https://www.nice.org.uk/Media/Default/About/what-we-do/NICEguidance/antimicrobial\%20guidance/summary-antimicrobial-prescribing-guidance.pdf (accessed 2 Dec 2020).

11. Gulliford MC, Dregan A, Moore MV, et al. Continued high rates of antibiotic prescribing to adults with respiratory tract infection: survey of 568 UK general practices. BMJ Open 2014; 4(10): e006245. DOI: https://doi.org/10.1136/ bmjopen-2014-006245

12. Smieszek T, Pouwels KB, Dolk FCK, et al. Potential for reducing inappropriate antibiotic prescribing in English primary care. J Antimicrob Chemother 2018; 73(suppl_2): ii36-ii43. DOI: https://doi.org/10.1093/jac/dkx500 
13. Wakeman $\mathrm{M}$, Cork T, Watwood D. A pilot study investigating point of care C-reactive protein (POC CRP) testing in community pharmacy to deliver appropriate interventions in respiratory tract infections (RTIs). J Pharm Pharmacol 2019; 71(s1): 11-12.

14. Brant $\mathrm{H}$, Atherton $\mathrm{H}$, Ziebland $\mathrm{S}$, et al. Using alternatives to face-to-face consultations: a survey of prevalence and attitudes in general practice. Br J Gen Pract 2016; 66(648): e460-e466. DOI: https://doi.org/10.3399/ bjgp16X685597

15. Little $\mathrm{P}$, Moore $\mathrm{M}$, Kelly $\mathrm{J}$, et al. Delayed antibiotic prescribing strategies for respiratory tract infections in primary care: pragmatic, factorial, randomised controlled trial. BMJ 2014; 348: g1606: g1606: . DOI: https://doi.org/10. 1136/bmj.g1606

16. Spurling GK, Del Mar CB, Dooley L, et al. Delayed antibiotic prescriptions for respiratory infections. Cochrane Database Syst Rev 2017; 9(9): CD004417. DOI: https://doi.org/10.1002/14651858.CD004417.pub5

17. Little P. Delayed prescribing of antibiotics for upper respiratory tract infection. BMJ 2005; 331(7512): 301-302. DOI: https://doi.org/10.1136/bmj.331.7512.301

18. Aabenhus R, Jensen J-US, Jørgensen KJ, et al. Biomarkers as point-of-care tests to guide prescription of antibiotics in patients with acute respiratory infections in primary care. Cochrane Database Syst Rev 2014; 15(2): CD010130. DOI: https://doi.org/10.1002/14651858.CD010130.pub2

19. Stanton N, Francis NA, Butler CC. Reducing uncertainty in managing respiratory tract infections in primary care. $\mathrm{Br}$ J Gen Pract 2010; 60(581): e466-e475. DOI: https://doi.org/10.3399/bjgp10X544104

20. Huang $Y$, Chen R, Wu T, et al. Association between point-of-care CRP testing and antibiotic prescribing in respiratory tract infections: a systematic review and meta-analysis of primary care studies. Br J Gen Pract 2013; 63(616): e787-e794. DOI: https://doi.org/10.3399/bjgp13X674477

21. Eley CV, Sharma A, Lecky DM, et al. Qualitative study to explore the views of general practice staff on the use of point-of-care $C$ reactive protein testing for the management of lower respiratory tract infections in routine general practice in England. BMJ Open 2018; 8(10): e023925. DOI: https://doi.org/10.1136/bmjopen-2018-023925

22. Hurt L, Ashfield-Watt $P$, Townson J, et al. Cohort profile: HealthWise Wales. A research register and population health data platform with linkage to National Health Service data sets in Wales. BMJ Open 2019; 9(12): e031705. DOI: https://doi.org/10.1136/bmjopen-2019-031705

23. McNulty CAM, Nichols T, French DP, et al. Expectations for consultations and antibiotics for respiratory tract infection in primary care: the RTI clinical iceberg. Br J Gen Pract 2013; 63(612): e429-e436. DOI: https://doi.org/ 10.3399/bjgp13X669149

24. Welsh Government. Welsh Index of Multiple Deprivation. 2014; https://gov.wales/welsh-index-multiple-deprivation (accessed 25 Feb 2021).

25. Welsh Government. SAIL Databank. 2019; https://saildatabank.com (accessed 2 Dec 2020).

26. Jones KH, Ford DV, Lyons RA. The Sail Databank: 10 years of spearheading data privacy and research utility, 2007-2017. 2017; https://saildatabank.com/wp-content/uploads/SAIL_10_year_anniversary_brochure.pdf (accessed 2 Dec 2020).

27. Coates S. Overview of the UK population: November 2018. 2018; https://www.ons.gov.uk/peoplepopulation andcommunity/populationandmigration/populationestimates/articles/overviewoftheukpopulation/november2018 (accessed 2 Dec 2020).

28. Welsh Government. National survey for Wales, 2017-18: internet use and digital skills. 2018; https://gov.wales/ sites/default/files/statistics-and-research/2019-01/national-survey-wales-internet-use-digital-skills-2017-18.pdf (accessed 3 Dec 2020).

29. Cornford CS, Morgan M, Ridsdale L. Why do mothers consult when their children cough? Fam Pract 1993; 10(2): 193-196. DOI: https://doi.org/10.1093/fampra/10.2.193

30. McNulty CAM, Lecky DM, Hawking MKD, et al. Delayed/back up antibiotic prescriptions: what do the public think? BMJ Open 2015; 5(11): e009748. DOI: https://doi.org/10.1136/bmjopen-2015-009748

31. McNulty C. Personal communication. 2020.

32. McDermott $L$, Leydon GM, Halls A, et al. Qualitative interview study of antibiotics and self-management strategies for respiratory infections in primary care. BMJ Open 2017; 7(11): e016903. DOI: https://doi.org/10.1136/bmjopen2017-016903

33. Lum EPM, Page K, Nissen L, et al. Australian consumer perspectives, attitudes and behaviours on antibiotic use and antibiotic resistance: a qualitative study with implications for public health policy and practice. BMC Public Health 2017; 17(1): 799. DOI: https://doi.org/10.1186/s12889-017-4813-7

34. Peters S, Rowbotham S, Chisholm A, et al. Managing self-limiting respiratory tract infections: a qualitative study of the usefulness of the delayed prescribing strategy. Br J Gen Pract 2011; 61(590): e579-e589. DOI: https://doi.org/ 10.3399/bjgp11X593866

35. Ryves R, Eyles C, Moore M, et al. Understanding the delayed prescribing of antibiotics for respiratory tract infection in primary care: a qualitative analysis. BMJ Open 2016; 6(11): e011882. DOI: https://doi.org/10.1136/ bmjopen-2016-011882

36. Donaghy $\mathrm{E}$, Atherton $\mathrm{H}$, Hammersley $\mathrm{V}$, et al. Acceptability, benefits, and challenges of video consulting: a qualitative study in primary care. Br J Gen Pract 2019; 69(686): e586-e594. DOI: https://doi.org/10.3399/ bjgp19X704141

37. Atherton H. Digitally enabled primary care: the emperor's new clothes? Br J Gen Pract 2019; 69(686): 420-421. DOI: https://doi.org/10.3399/bjgp19X705125

38. Butler CC, Gillespie D, White $P$, et al. C-Reactive protein testing to guide antibiotic prescribing for COPD exacerbations. N Engl J Med 2019; 381(2): 111-120. DOI: https://doi.org/10.1056/NEJMoa1803185 